Leading Article

\title{
End stage renal disease in sickle cell disease: future directions
}

\author{
C.R.V. Tomson
}

Department of Nephrology, St Bartholomew's Hospital, London ECIA 7BE, UK

Prolonged survival in homozygous sickle cell anaemia has allowed increasing recognition of the effect of this disease on a number of organs including the kidney. Decreased concentrating and diluting ability and decreased urine acidification are early features; ${ }^{1-5}$ hyperkalaemia may occur, with or without hyporeninaemic hypoaldosteronism. ${ }^{6}$ Children and young adults have increased total renal blood flow and increased glomerular filtration rate (measured isotopically). Recurrent haematuria may occur; in several series this has been 4-5 times more frequent from the left kidney than the right, ${ }^{7,8}$ although the proposed explanation (increased venous pressure due to the greater length of the left renal vein) has never been proven. Papillary necrosis may occur as a result of medullary infarction due to sickling or due to analgesic nephropathy. Lastly, and of the greatest prognostic importance, glomerular disease may occur, heralding (at least in some patients) an inexorable decline to end-stage renal failure.

Pathologically, the most striking feature is medullary fibrosis and loss of vasa recta. ${ }^{4,9}$ These findings are readily explained by the increased viscosity, increased osmolality, and decreased oxygen content of the medulla, ${ }^{2,10}$ resulting in occlusion of medullary vessels by sickled cells and development of collateral vessels which are not oriented to permit countercurrent exchange.

Glomerular histological abnormalities have been reported even in children with supranormal glomerular filtration rate. ${ }^{11-14} \mathrm{~A}$ variety of histological appearances have been described, most frequently focal segmental glomerulosclerosis and mesangiocapillary (membranoproliferative) glomerulonephritis and occasionally membranous glomerulonephritis. Glomerular hypertrophy has been noted in several studies. ${ }^{11,13}$ No longitudinal studies have been performed, and it is impossible to state with certainty whether these histological appear-

Correspondence: C.R.V. Tomson, D.M., M.R.C.P. Received: 14 May 1992 ances simply represent different stages in the evolution of a single disease, or whether there is more than one cause of glomerular disease in sickle cell anaemia, but the presence of immune complexes in some and their absence in other biopsies suggest the latter. The pathogenesis of these changes is less certain than that of the medullary changes. Possible causative factors include mesangial phagocytosis of sickled cells, ${ }^{15}$ an immune complex glomerulonephritis caused by release of autoantigens from ischaemic tubules, ${ }^{16}$ and self-sustaining glomerular injury caused by glomerular hyperfiltration ${ }^{17}$ and glomerular hypertrophy. ${ }^{18,19}$ There is no convincing evidence of an increased incidence of post-streptococcal glomerulonephritis.

Glomerular disease may present with proteinuria (sometimes in the nephrotic range), microscopic haematuria and hypertension. Progressive renal impairment may first be noted because of worsening anaemia, owing to impairment of erythropoietin production. ${ }^{20,21}$ This may be worsened by aplastic crises, although there is no evidence that these are more common after the development of sickle glomerulopathy. Repeated transfusions at this stage may result in iron overload. Recognition of the severity of renal involvement may be delayed if reliance is placed on measurement of serum creatinine or creatinine clearance. Serum creatinine may rise outside the normal range only when glomerular filtration rate has fallen well below $50 \%$ of normal. This is partly due to the reciprocal relationship between serum creatinine concentration and glomerular filtration rate, but also because of increased tubular secretion of creatinine in patients with sickle nephropathy, ${ }^{22,23}$ creatinine clearance therefore overestimates glomerular filtration rate in these patients.

The first reports of long-term survival of sickle cell patients on dialysis appeared in $1974 .{ }^{24,25}$ Since then increasing numbers of patients have been treated with haemodialysis ${ }^{26}$ and peritoneal dialysis, although sickle cell anaemia remains a rare cause of renal failure in dialysis registries. ${ }^{27}$ The course of dialysis may be complicated by throm- 
botic episodes including priapism ${ }^{28}$ and ischaemic intestinal necrosis, ${ }^{29}$ although the exaggerated anaemia associated with dialysis may offer partial protection against sickling, particularly if treated by regular transfusions. However, regular transfusions, particularly from racially unmatched donors, may increase the risk of sensitization to HLA antigens..$^{30}$ This had led to clinical interest in the use of recombinant human erythropoietin in the treatment of the profound anaemia which accompanies sickle cell disease in renal failure. As mentioned above, erythropoietin deficiency is an early feature of sickle nephropathy. Early clinical studies of the use of recombinant human erythropoietin have shown that it is possible to stimulate native erythropoiesis in patients with renal impairment, but that much higher doses are required than in other patients with renal failure, presumably due to ineffective erythropoiesis leading to apparent marrow resistance to this drug. ${ }^{31-33}$ As in patients without renal failure, ${ }^{34}$ early hopes that pulses of erythropoietin might result in stimulation of haemoglobin $F$ production (and thus protect against sickling) have not been confirmed.

Successful renal transplantation has also been reported, ${ }^{35-37}$ although it may be complicated by stroke ${ }^{36}$ transplant artery thrombosis ${ }^{38}$ and painful crises ${ }^{39}$ particularly as the haemoglobin level rises. Exchange transfusion may be required from the time of transplantation to prevent these complications. Initial analyses suggested that survival of patients with sickle cell anaemia on dialysis was comparable to that of patients with other primary renal diseases. ${ }^{27}$ However, these reports were based on small numbers and are subject to reporting and selection bias.

A recent report from Los Angeles has provided important new information on a cohort of 725 patients with homozygous sickle cell disease and 209 patients with sickle $C$ disease followed over 25 years. ${ }^{40}$ Thirty-six patients developed renal failure $(4.2 \%$ of the sickle cell patients and $2.4 \%$ of the sickle C patients), with a median age of onset of 23.1 and 49.9 years, respectively. The development of renal impairment was heralded by evidence of early renal involvement, including ineffective erythropoiesis, hypertension, proteinuria (including the nephrotic syndrome), and haematuria. Patients with renal failure were three times more likely to have a history of chronic restrictive lung disease, leg ulcers, or stroke than patients without renal failure. Cardiac function was not systematically investigated. No relationship was found between the number of painful crises during childhood and the later development of renal impairment, but analgesic consumption itself was not documented. In a subset analysis of patients who had undergone Southern blot analysis of beta ${ }^{s}$ gene cluster haplotypes, 9/10 patients with renal impairment had the Central African Republic haplotype, compared to a frequency of $33 \%$ in the general population and $26 \%$ in a control group from the same cohorte who did not develop renal impairment. The same authors have previously reported that this hap-on lotype is also associated with a greater risk of failure of other organs..$^{41,42}$ The mechanisms by을 which this haplotype confers a greater risk of organ $\frac{\bar{c}}{\vec{D}}$ damage has not been identified.

The most concerning aspect of this importanto report is the appalling life expectancy of sickle cellpatients who develop renal failure, far worse than? would be expected for these relatively young $\vec{\omega}$ patients starting renal replacement therapy. Eigh- $\odot$ teen of the 36 patients who developed renal failure died during the follow-up period, a median of 43 . years after development of renal failure, defined as a creatinine concentration above the normal range. Although few details are given, it seems that most $\varnothing$ of these deaths were due to cardiac disease, with $\nsucc$ 'cardiac failure', pericardial and pleural effusions, or ascites and intracranial haemorrhage. Seizures and음 recurrent 'adult respiratory distress syndrome' are also described. Of the remaining 18 patients with renal failure, 13 required dialysis and three under- 0 went transplantation. ${ }^{40}$

Why does renal failure carry such a dismgl $\vec{\overrightarrow{ }}$ prognosis in this group of patients, when patienes $₫$ with other renal diseases have an increasingly gogi ? life expectancy on dialysis and transplant progran:-0 mes? There are several possible explanations.

Firstly, institution of dialysis may have been unduly delayed, allowing the development of $\stackrel{0}{\not}$ severe complications of renal failure. In particular, $\stackrel{\mathbb{2}}{\square}$ it is possible that the patients who are described as $\overrightarrow{\vec{\partial}}$ having recurrent 'respiratory distress syndrome' $\frac{O}{3}$ were in fact suffering from recurrent non-cardiogenic pulmonary oedema due to fluid retention. Similarly, it is possible that many of the features of 'cardiac failure' described were in fact due to fluid 3 . retention as a result of advanced renal failure, and $\dot{\sigma}$ that the intracranial haemorrhages described were due to severe nephrogenic hypertension. Possibly, $ᄋ$ as for diabetics, ${ }^{43}$ dialysis should be instituted at $₹$ lower levels of urea and creatinine than in patients 은 with other renal diseases, particularly in view of the $>$ above mentioned unreliability of creatinine as a filtration marker in sickle nephropathy.

Secondly, undernutrition and underdialysis are of well known to confer increased morbidity and $N$ mortality in patients receiving dialysis. ${ }^{44,45}$ No $\underset{\omega}{\mathcal{N}}$ information is given about dialysis prescriptions or $\bar{O}$ assessments of adequacy of dialysis.

The third, and probably most important possibility, is that patients with sickle glomerulopathy $\stackrel{\mathscr{Q}}{\rightarrow}$ also have more extensive damage to other organs 0 than patients without glomerulopathy. In particular, it seems likely that there was more extensive cardiac damage in this group of patients. Cardiac 
damage may be difficult to recognize using traditional indices of systolic function because of increased preload and peripheral vasodilatation resulting from chronic anaemia, but may be clearly revealed by use of load-independent end-systolic indices. ${ }^{46}$ The pathogenesis of cardiac disease may include sickling in the coronary microcirculation, iron overload, and cor pulmonale due to sickling in the pulmonary circulation. ${ }^{47}$

Lastly, it should be remembered that many of the patients in this report entered dialysis programmes 10 or even 15 years ago, when dialysis was in its infancy.

What of the future? Much has been learnt about the pathogenesis of sickle glomerulopathy. The condition can be recognized early by paying attention to the results of urinalysis, the development of hypertension, and falling haemoglobin concentration. There is early evidence that angiotensin converting enzyme inhibitors, as in diabetic nephropathy, may lessen proteinuria and prevent progressive glomerular injury; ${ }^{48}$ protein restriction may also be of benefit, as in other progressive renal

\section{References}

1. Buckalew, V.M. \& Someren, A. Renal manifestations of sickle cell disease. Arch Intern Med 1974, 133: 660-669.

2. Alleyne, G.A.O., Statius van Eps, L.W., Addae, S.K., Nicholson, G.D. \& Schouten, H. The kidney in sickle cell anemia. Kidney Int 1975, 7: 371-379.

3. Strauss, J., Zilleruelo, G. \& Abitbol, C. The kidney and haemoglobin S. Nephron 1986, 43: 241-245.

4. De Jong, P.E. \& Statius van Eps, L.W. Sickle cell nephropathy: new insights into its pathophysiology. Kidney Int 1985, 27: 711-717.

5. Allon, M. Renal abnormalities in sickle cell disease. Arch Intern Med 1990, 150: 501 - 504

6. De Fronzo, R.A. Hyperkalaemia and hyporeninaemic hypoaldosteronism. Kidney Int 1980, 17: 118-134.

7. Case Records of the Massachusetts General Hospital. Case no. 25-1985. $N$ Engl J Med 1985, 312: 1623-1631.

8. Qunibi, W.Y. Renal autotransplantation for severe sickle cell haematuria. Lancet 1988, i: 236-237.

9. Statius van Eps, L.W., Pinedo-Veels, C., deVries, C.H. \& de Koning, J. Nature of the concentration defect in sickle cell nephropathy: microradioangiographic studies. Lancet 1970 , i: $450-452$.

10. Epstein, F.H. Hypoxia of the renal medulla. $Q J$ Med 1985 , 57: $807-810$.

11. Pitcock, J.A., Muirhead, E.E., Hatch, F.E., Johnson, J.G. \& Kelly, B.J. Early renal changes in sickle cell anemia. Arch Path 1970, 90: 403-405.

12. Walker, B.R., Alexander, F., Birdsall, T.R. \& Warren, R.L. Glomerular lesions in sickle cell nephropathy. JAMA 1971, 215: $437-440$.

13. Elfenbein, I.B., Patchetsky, A., Schwartz, W. \& Weinstein, A.G. Pathology of the glomerulus in sickle cell anemia with and without nephrotic syndrome. Am J Pathol 1974, 77: 357-376.

14. Tejani, A., Phadke, K., Adamson, O., Nicastri, A., Chen, C.K. \& Sen, D. Renal lesions in sickle cell nephropathy in children. Nephron 1985, 39: 352-355. diseases. ${ }^{49}$ The timing of initiation of dialysis treatment should depend as much on clinical features such as diuretic-resistant fluid retention, anorexia and nausea rather than waiting for the serum urea or creatine to reach pre-defined values. Once dialysis has been initiated, careful attention should be paid to avoidance of fluid overload, which may contribute to cardiac damage, and to adequate nutrition and urea removal. Attention should be paid to avoiding iron overload and consideration given to chelation therapy in multiply transfused patients. Hydroxyurea, ${ }^{34,50}$ in combination with erythropoietin, may improve erythropoiesis and thus lessen the chances both of iron overload and of HLA sensitization. In the future, this and other complications of sickle cell anaemia may be totally preventable by gene therapy. In the meantime, future clinical studies should concentrate on the exact causes of death in this group of patients; and on the prevention of progressive renal disease in patients with glomerulopathy.

15. Bakir, A.A., Hathiwala, S.C., Ainis, H. et al. Prognosis of the nephrotic syndrome in sickle glomerulopathy. Am J Nephrol 1987, 7: 110-115.

16. Pardo, V., Strauss, J., Kramer, H., Ozawa, T. \& McIntosh, R.M. Nephropathy associated with sickle cell anemia: an autologous immune complex nephritis. II. Clinicopathologic study of seven patients. Am J Med 1975, 59: 650-659.

17. Brenner, B.M., Meyer, T.W. \& Hostetter, T.H. Dietary protein intake and the progressive nature of kidney disease: the role of hemodynamically mediated glomerular injury in the pathogenesis of progressive glomerular sclerosis in aging, renal ablation, and intrinsic renal disease. $N$ Engl J Med 1982, 307: 652-659.

18. Yoshida, Y., Fogo, A. \& Ichikawa, I. Glomerular hemodynamic changes vs. hypertrophy in experimental glomerular sclerosis. Kidney Int 1989, 35: 654-660.

19. Fries, J.W.U., Sandstrom, D.J., Meyer, T.W. \& Rennke, H.G. Glomerular hypertrophy and epithelial cell injury modulate progressive glomerulosclerosis in the rat. $\mathbf{L a b}$ Invest 1989, 60: 205-218.

20. Morgan, A.G., Gruber, C.A. \& Serjeant, G.R. Erythropoietin and renal function in sickle-cell disease. $\mathrm{Br}$ Med $\mathrm{J}$ 1982, 285: 1686-1688.

21. Sherwood, J.B., Goldwasser, E., Chilcote, R., Carmichael, L.D. \& Nagel, R.L. Sickle cell anemia patients have low erythropoietin levels for their degree of anemia. Blood 1985, 67: 46-49.

22. De Jong, P.E., de Jong-van der Berg, T.W., Sewrajsingh, G.S., Schouten, H., Donker, A.J.M. \& Statius van Eps, L.W. The influence of indomethacin on renal haemodynamics in sickle cell anaemia. Clin Sci 1980, 59: 245-250.

23. Allon, M., Lawson, L., Eckman, J.R., Delaney, V. \& Bourke, E. Effects of nonsteroidal antiinflammatory drugs on renal function in sickle cell anemia. Kidney Int 1988, 34: 500-506.

24. Friedman, E.A., Sreepada Roao, T.K., Sprung, C.L. et al. Uremia in sickle cell anemia treated by maintenance hemodialysis. N Engl J Med 1974, 291: 431-435. 
25. Cruz, I.A., Hosten, A.O., Dillard, M.G. \& Castro, O.L. Advanced renal failure in patients with sickle cell anemia: clinical course and prognosis. J Natl Med Ass 1982, 74: 1103-1109.

26. Gold, D.D. Hemodialysis and transfusions for uremic patients with sickle cell disease. $N$ Engl J Med 1974, 291: $1361-1364$.

27. Nissenson, A.R. \& Port, F.K. Outcome of end-stage renal disease in patients with rare causes of renal failure. 1. Inherited and metabolic disorders. $Q J$ Med 1989, 73: $1055-1062$.

28. Singhal, P.C., Lynn, R.I. \& Scharschmidt, L.A. Priapism and dialysis. Am J Nephrol 1986, 6: 358-361.

29. Engelhardt, T., Pulitzer, D.R. \& Etheredge, E.E. Ischemic intestinal necrosis as a cause of atypical abdominal pain in a sickle cell patient. J Natl Med Ass 1989, 81: 1077, 1080-1084, 1087-1088.

30. Vichinsky, E.P., Earles, A., Johnson, R.A., Hoag, S., Williams, A. \& Lubion, B. Alloimmunization in sickle cell anemia and transfusion of racially unmatched blood. $N$ Engl J Med 1990, 322: 1617-1621.

31. Steinberg, M.H. Erythropoietin for anemia of renal failure in sickle cell disease. $N$ Engl J Med 1991, 324: 1369-1370.

32. Roger, S.D., MacDougall, I.C., Thuraisingham, R.C. \& Raine, A.E.G. Erythropoietin in anemia of renal failure in sickle cell disease. $N$ Engl J Med 1991, 325: 1175-1176.

33. Tomson, C.R.V., Edmunds, M.E., Chambers, K., Bricknell, S., Feehally, J. \& Walls, J. Effect of human recombinant erythropoietin on erythropoiesis in homozygous sickle cell anaemia and renal failure. Nephrol Dial Transplant 1992 (in press).

34. Goldberg, M.A., Brugnara, C., Dover, G.J., Schapira, L., Charache, S. \& Bunn, H.F. Treatment of sickle cell anemia with hydroxyurea and erythropoietin. N Engl J Med 1990, 323: $366-372$.

35. Chatterjee, S.N. National study on natural history of renal allografts in sickle cell disease or trait. Nephron 1980, 25: 199-201.

36. Chatterjee, S.N. National study in natural history of renal allografts in sickle cell disease or trait: a second report. Transplant Proc 1987, 19 (Suppl 2): 33-35.

37. Barber, W.H., Deirhoi, M.H., Julian, B.A. et al. Renal transplantation in sickle cell anemia and sickle disease. Clin Transplantation 1987, 1: 169-175.
38. Donnelly, P.K., Edmunds, M.E. \& O'Reilly, K. Renal transplantation in sickle cell disease. Lancet 1988, ii: 229 .

39. Spector, D., Zachary, J.B., Sterioff, S. \& Millan, J. Painful crises following renal transplantation in sickle cell anemia. Am J Med 1978, 64: 835-839.

40. Powars, D.R., Elliott-Mills, D.D., Chan, L. et al. Chronic $\stackrel{\vec{P}}{+}$ renal failure in sickle cell disease: risk factors, clinical course, and mortality. Ann Intern Med 1991, 115: 614-620.

41. Powars, D.R., Chan, I. \& Schroeder, W.A. The influence of $\bar{c}$ fetal hemoglobin on the clinical expression of sickle cell? anemia. Ann N Y Acad Sci 1989, 565: 262-278.

42. Powars, D., Chan, L.S. \& Schroeder, W.A.S. The variablen expression of sickle cell disease is genetically determined. Semin Haematol 1990, 27: 360-376.

43. Rocher, L. Diabetic nephropathy: the internist's role. ArchIntern Med 1990, 150: 26-28.

44. Degoulet, P., Legrain, M., Reach, I. et al. Mortality risk factors in patients treated by chronic hemodialysis. Nephron 1982, 31: 103-110.

45. Hull, A.R. \& Parker, T.F. Proceedings from the morbidity, mortality and prescription of dialysis symposium, Dallas, $\infty$ TX, September 15 to 17, 1989. Am J Kidney Dis 1990, 15: 375-383.

46. Denenberg, B.S., Criner, G., Jones, R. \& Spann, J.F. Cardiac function in sickle cell anemia. Am J Cardiol 1983, 51: Vे 1674-1678.

47. Lindsay, J., Meshel, J.C. \& Patterson, R.H. The cardiovas-음 cular manifestations of sickle cell disease. Arch Intern Med $\rightarrow$ 1974, 133: 643-651.

48. Falk, R.J., Scheinman, J., Phillips, G., Orringer, E., Johnson, A. \& Jennette, J.C. Prevalence and pathologic features of sickle cell nephropathy and response to inhibition of angiotensin-converting enzyme. $N$ Engl J Med 1992, 326: 910-915.

49. Fouque, D., Laville, M., Boissel, J.P., Chifflet, R., Labeetw, M. \& Zech, P.Y. Controlled low protein diets in chronic re 1 insufficiency: meta-analysis. $\mathrm{Br}$ Med $J$ 1992, 304: 216-227

50. Rodgers, G.P., Dover, G.J., Noguchi, C.T., Schechter, A.N. $\&$ Niehuis, A.W. Haematologic responses of patients with sickle cell disease to treatment with hydroxyurea. $N$ Engl $J$ Med 1990, 322: 1037-1045. 